\title{
Corporate Profit Growth and Variability in US Unemployment Rate
}

\author{
Rexford Abaidoo \\ Correspondence: Rexford Abaidoo, Department of Business, Management and Accounting, University of Maryland \\ Eastern Shore, USA
}

Received: April 18, 2012

Accepted: May 16, $2012 \quad$ Published: July 1, 2012

doi:10.5539/ijef.v4n7p3

URL: http://dx.doi.org/10.5539/ijef.v4n7p3

\begin{abstract}
This study investigates effects of corporate profit growth, macroeconomic uncertainty and other key economic indicators on the potential for lower unemployment condition in the US economy. Using marginal effect probit estimates, this study finds that, sustained growth in corporate profit and appreciable economic growth (as measured by GDP growth) are significant in determining the likelihood of achieving lower unemployment rate. Overall results however, show that among variables tested, reduction in perceived macroeconomic uncertainty is the dominant variable with the potential to significantly impact the likelihood of having lower unemployment rate.
\end{abstract}

Keywords: investments growth, corporate profits, unemployment rate, probit marginal effects, macroeconomic uncertainty

\section{JEL Classification: E27, E24}

\section{Introduction}

Historically, corporate profit growth in both developed and developing economies around the world has been perceived as a product of vibrant macroeconomic conditions. Sustained growth in corporate profit has also been shown to reflect to some degree, the trajectory of prevailing macroeconomic policies being pursued and growth augmenting external factors. The macroeconomic literature for instance, features legion of empirical studies which addresses how macroeconomic dynamics impact corporate performance, and ultimately, profitability. Reviewed studies suggests that economies which exhibit specific growth augmenting features (low interest rates, low corporate taxes, etc.) are more likely to support significant firm growth through new projects and other long term investments; a condition which enhances the potential for appreciable growth in firm profit. Firm profit growth due to aforementioned enabling economic conditions, has also been projected to be integral in spurring growth in investments through utilization of undistributed profits. This tendency to embark on new short or long term investments due to sustained growth in firm profits, and how such condition ultimately impacts prevailing unemployment rate is the focus of this empirical study. Recent debates on trend dynamics between corporate profit growth and persistently high unemployment rate have hinged on apparent conflict between traditionally projected negative correlation between the two indicators and recent diverging trend according to available data. This projected negative association between corporate profit growth and unemployment rate is predicated on expected positive association between corporate profits and investments growth; with investment growth acting as the conduit between rate of growth in corporate profit and unemployment rate. Related literature show that this projected positive association between growth in firm profits and investment growth is not without merit. The theory of the firm for instance, projects that, highly profitable firms are more likely to be characterized by or tend to exhibit relatively high propensity to embark on new investments because of excess revenue over cost of operations. Proponents of this positive association (between corporate profit and investment growth) further argue that, sustained growth in firm profit reflects higher return on investment; a condition which makes it more likely that firms experiencing growth in profits will choose to channel more funds into additional ventures in attempt to compete away prevailing profits in the market place. In other words, the drive to enhance profitability ultimately drives additional growth in investment.

In addition to this projected positive association between corporate profit trend and investment growth, reviewed literature further provide sufficient evidence in support of inverse relationship between investment growth within an economy and prevailing unemployment rate. Available evidence suggests that, as firms expand through investments in new projects, the expansion process, all things being equal, necessitates demand for labor, ultimately bringing about a decline in prevailing unemployment rate. Although, results vary significantly on the extent to which investment growth impact prevailing unemployment rates, reviewed studies focusing on the investment 
growth-unemployment rate nexus, tend to support strong negative relationship between the two variables. For instance, Ashipala and Eita (2010) showed that investment growth has significant depressing effect on prevailing unemployment rate. Additionally, Brady and Wallace (2000), Sawyer (2002), Herbertson and Zoega (2002), Smith and Zoega (2005), Kapadia (2005), Arestis, et al. (2007), Karanassou, et al. (2008), have all reached similar conclusions suggesting an inverse relationship between aggregate investment growth and unemployment rate.

This study hypothesize that if investment growth correlates negatively with unemployment rates as documented in stated empirical studies; and corporate profits growth is projected to correlates positively with investment growth, then by logical necessity, corporate profits growth should correlates negatively with prevailing unemployment rate all things being equal. In order words, if investment growth inversely correlates with prevailing rate of unemployment, and the same economic indicator is projected to have positive relationship with corporate profit growth, then deductively, corporate profit growth would be expected to have negative impact on unemployment rate, all things being equal. Recent United States (US) unemployment conditions and corporate profits growth dynamics characterizing firms in the various sectors of the economy however, seems to suggest a paradigm shift from this projected dynamic relationship. Unemployment rates (2010 and 2012 trends) among various sectors of the economy, and profitability trends as reported among most US firms seems to challenge this projected inverse relationship between corporate profit growth and unemployment rate.

Data from US Bureau of Economic Analysis (BEA) and St. Louis Fed data on the two variables, show that unemployment rates since the 2008 recession continue to be persistently high with relative downward stickiness; corporate profits growth among firms however continue to soar from quarter to quarter. Additionally, the data further show that Gross Domestic Product (GDP) growth continue to be significantly week with no indication that the trend will attain its pre-2008 levels any time soon; a condition which suggests investments growth expected from soaring corporate profits has so far failed to materialize or are far below levels needed to significantly impact economic growth. This apparent failure of investment growth and unemployment rate to reflect to sustained growth in corporate profit in recent post recession economic environment, presents unique challenge for both economists and business analysts. The condition calls for critical re-examination of the data in order to explain this evolving macroeconomic phenomenon. This emerging conflict in projected relationship between corporate profit growth and unemployment rate further calls for the need to re-assess traditional projections by examining critical auxiliary factors which might help explain the recent trend. The condition additionally calls for identification of non-traditional factors with the potential to explain this emerging relationship between corporate profits growth and unemployment conditions in the US economy.

This study investigates the relationship between these two variables in an attempt to understand the dynamics at play in recent mismatch between corporate profits growth and unemployment conditions in the US economy. The goal is to verify how corporate profit growth dynamics influence the potential for lower unemployment conditions. This study further analyze the extent to which other key economic and performance indicators such as interest rates, labor cost, fixed investment growth, productivity level, GDP growth etc, influence potential for lower unemployment conditions. Additionally, this study also verifies how macroeconomic uncertainty impacts or moderates the relationship between the potential for lower unemployment rate and corporate profits growth. This study employs both graphical and empirical tests in its attempt to explain recent corporate profit growth and unemployment rate nexus. Attempts will also be made to find out if recent corporate profit growth and unemployment trend is unique in the historical data.

The rest of the study is structured as follows: Data on trends in US corporate profits growth and unemployment rates as well as GDP growth are first reviewed. The section also disaggregate and provide a thorough analysis of recent corporate profit growth dynamics, GDP growth and unemployment conditions as detailed in releases provided by the BEA and St. Louis Fed respectively. Relationships between unemployment rate and GDP growth; and unemployment rate and corporate profits growth are also discussed in the sequence. Section three introduces models used in testing for specific features associated with individual variables and also presents results of various empirical tests conducted. Finally, analysis and test results verifying the extent to which employed variables impact the likelihood of having lower unemployment conditions are presented followed by conclusions and possible policy implications of the results.

\section{Examining Factors Influencing US Unemployment Conditions}

Recent imbalance between US corporate profit growth and unemployment conditions has challenged presumed negative association between the two variables. To re-examine core factors responsible for recent fluctuations in US unemployment conditions, and the role of corporate profit growth specifically, this section reviews historical data trend conditions for the two variables. Preliminary review of the data, show that the traditional view projecting 
negative association between corporate profits growth and unemployment conditions is not entirely supported. Post recession quarterly reports for instance show continual growth in corporate profits among most US firms; at the same time however, unemployment conditions remain persistently high contrary to expected negative association between the two variables. Although this study expects unemployment rate to lag investments and economic growth as well as corporate profitability as economic models project, it is also of the view that recent conditions cannot fully account for the relatively high unemployment conditions characterizing the US economy. Empirical examination of factors responsible for this condition (growth in corporate profits and rising unemployment rate) is scanty among reviewed literature; however, attempts at explaining the phenomenon continue to evolve as the US economy transitions into what some analysts have termed the "new normal" (relatively high unemployment rate and sustained corporate profit growth). Ongoing debate on the factors responsible for the present unemployment conditions however suggests that, weak US manufacturing sector growth, macroeconomic uncertainty, globalization, lingering effect of the 2008 recession, weak global economic performance etc, might be responsible for the present trend. The following section reviews the role of these factors in US unemployment conditions.

According to Michael Spence (Note 1), growing unemployment conditions in the US could be attributed to evolving trends in globalization rather than domestic factors espoused by some analysts. In his analysis of the factors responsible for growing unemployment conditions in the US, Spence showed that growing globalization has and continue to reallocate significant part of international supply chain into developing economies around the world. This condition he contends has significantly impacted job growth patterns, and wages among most developed economies such as the US. According to his analysis, the trend has redistributed employment opportunities and incomes away from advanced economies such as the US into developing economies with relatively low operational cost and lax labor and environmental laws - conditions which contribute significantly to high operational cost in most advanced economies. Spence argues that, as multi-national firms and corporations move significant part of operations to low wage economies, advanced economies such as the US loose the potential to maintain robust employment conditions, leading to relatively high unemployment rate.

In order words, to Michael Spence, relatively high US unemployment conditions in recent years could be explained by features linked with trends in globalization (growing international economic integration) apart from domestic macroeconomic conditions. This conclusion suggests that policy makers might be significantly constrained in their efforts at lowering present unemployment conditions; in that, rational firms will continue to relocate substantial part of operations into economies characterized low operational cost, further worsening prevailing unemployment conditions. This study projects that continual flow of investments into developing economies by US firms has the potential to enhance profitability among parent companies in US with no significant effect on domestic unemployment rate. This condition could then, to some degree help in explaining recent corporate profit growth-unemployment rate mismatch characterizing the US economy.

Domestic and global macroeconomic uncertainty has also been suggested as a dominant factor accounting for recent high US unemployment conditions. Proponents argue that growing uncertainties about long term repercussions of ongoing global financial system volatility, and weak domestic macroeconomic conditions has been responsible for continued depressed propensity to invest by domestic and international firms. Most firms according to proponents have shelved desire to embark on new projects with potential to augment employment growth because of perceived macroeconomic uncertainty or conflicting signals from policy makers in Washington on the economy. Supporters of this view point out that economic uncertainty makes it extremely difficult for firms to accurately forecast critical performance indicators and cash flows needed to assess viability of desired projects. This condition tends to have depressing impact on investments growth with significant negative effect on unemployment rate. Empirical studies on the effects of uncertainty on investment growth are quite extensive; however, conclusions diverge significantly on the extent to which uncertainty impact investment growth. Some of these studies suggest that the ultimate impact of uncertainty on investments growth depends on the apparent reversibility or otherwise of the investment venture in question. In order words, uncertainty might not entirely inhibits investment growth if such investment is readily reversible in the face of perceived failure with limited financial lose.

Reviewed studies on the average however, tend to favor negative association between macroeconomic uncertainty and investment growth. Ramey and Ramey (1995) and Asteriou and Price (2005) for instance, found significant negative relationship between investment growth and volatility (a proxy for uncertainty). Additionally, Federer (1993) and Driver and Moreton (1991), also found that macroeconomic uncertainty has negative impact on US equipment investment and UK manufacturing investment growth respectively. Similarly, Darby et al. (1998) also showed that real exchange rate uncertainty negatively impact investment growth in five Organization of Economic Cooperation and Development (OECD) economies. The case among developing economies further provide evidence in support of negative correlation between macroeconomic uncertainty and investments growth. Aizenman and 
Marion (1999), Edwards (1989), Moguillansky (2002), and Serven (1998) all document significant negative relationship between private investment and key economic instability or uncertainty. Domestically, growing political uncertainty about the trajectory of current policies is believed to a key factor explaining weak investment growth, hiring trends and unemployment rate in US economy.

\section{Examining Recent Corporate Profit Phenomenon and Unemployment Conditions}

Available data show that corporate profits have witnessed appreciable growth in recent quarters despite lingering effect of the 2008 economic recession. Corporate profits data between 1947 and 2011 show that recent growth in corporate profits is not only dramatic, but also unique with regards to its relationship with prevailing unemployment conditions. Post recession data shows that these two indicators have been treading in the same direction contrary to projections. A number of factors have been put forth in an attempt to explain continuing growth in corporate profits; and why the phenomenon has failed to have any significant impact on unemployment conditions in the country. Aside factors already alluded to above, lean production methods implemented in the wake of the 2008 recession leading to lower production cost has also been sighted as a key factor responsible for recent corporate profit growth. Proponents of this condition argue that 2008 recessionary conditions necessitated massive layoffs and the need to adopt efficient or lean operational methods. Consequently, firms are now able to achieve production targets with relatively limited number of employees and at relatively lower cost leading to higher profit margins. To analysts who espouse this train of thought, significant portion of recent corporate profits growth reflects elimination of huge labor cost which characterized pre-recession (2008) corporate operations and adoption of more efficient methods of operation.

Recent corporate profit growth and dismal unemployment conditions have also been attributed to growing international market integration and variations in growth conditions associated with individual economies around the world (Note 2). Most US corporations are known to have multinational subsidiaries responsible for significant portion of core business operations. General Motors, for instance, has significant part of its operations in budding economies in Asia. Growing market integration in recent years ensures that depressed growth in a domestic economy does not significantly impact overall corporate performance and profitability of the company as whole. Some analysts are of the view that recent growth in corporate profits among US firms can be attributed to growth in earnings from abroad among subsidiaries; and does not reflects domestic performance of the parent company or macroeconomic conditions. Significant portion of recent corporate profit growth is thus believed to have accrued from operations in markets still characterized by relatively robust growth such as the Chinese and the Indian economies. This condition according to some analysts, might explain why recent corporate profits growth conditions have failed to have significant impact on US investments growth and unemployment conditions.

\subsection{Structure of Recent Corporate Profit Growth}

According to BEA, corporate profits with inventory valuation and capital consumption adjustments grew by $\$ 61.2$ billion in the second quarter of 2011, compared to $\$ 19.0$ billion growth in the first quarter of the same year. BEA further report that current-production cash flow (net cash flow with inventory valuation adjustment) - that is, internal funds available to corporations for reinvestments also grew by $\$ 86.2$ billion in the second quarter of 2011, compared to $\$ 21.1$ billion in the first quarter. The Bureau also documents that tax on corporate income in the same period decreased by $\$ 1.8$ billion in the second quarter, in contrast to an increase of $\$ 17.6$ billion in the first quarter of the same year. Conditions which support the view that firms during these periods had access to significant portion of their revenue, bringing about significant growth in profits.

During this same period, Department of Commerce Release also documents that domestic profits of nonfinancial corporations increased by $\$ 80.8$ billion in the second quarter of 2011, compared to just $\$ 19.7$ billion recorded in the first quarter. In the same (second) quarter, BEA data further show that real gross value added of nonfinancial corporations increased significantly, and profits per unit of real value added also witnessed significant growth. According to BEA release, growth in profits, especially in the nonfinancial sector of the economy over this period in question, reflected significant decline in unit labor and non-labor costs of operations among firms over the period. This corporate profits growth dynamics forms the basis of ongoing debate about the role of corporate profits growth in US unemployment conditions; and the need to re-visit factors responsible for this perceived conflicting phenomenon.

GDP growth data analysis over the same period further indicates the trend is still weak compared to pre-recession levels even though corporate profits continue to soar from quarter to quarter. In its September 29, 2011 press release, BEA report on real personal consumption expenditure growth (a significant component of GDP growth) showed only 0.7 percent growth in the second quarter, compared to 2.1 percent growth in the first. Durable goods production during the same period (second quarter) is shown to have declined 5.3 percent in contrast to 11.7 percent growth in the first. Nondurable goods in the same period also grew by only 0.2 percent in the second quarter of 2011 , compared to 1.6 
percent growth in the first quarter of the same year. These trends further show that persistence growth in corporate profits over the same period had little or no measureable impact on prevailing GDP growth; a key condition necessary for employment growth.

\subsection{Corporate Profit Growth between $Q_{l}$ (2008) - $Q_{1}$ (2011)}

Figure 1 charts corporate profit growth among US firms between the first quarter of 2008 and the first quarter of 2011. With the exception of the fourth quarter of 2008, figure 1 show there has been sustained growth in corporate profits with substantial spike in the first quarter of 2011.

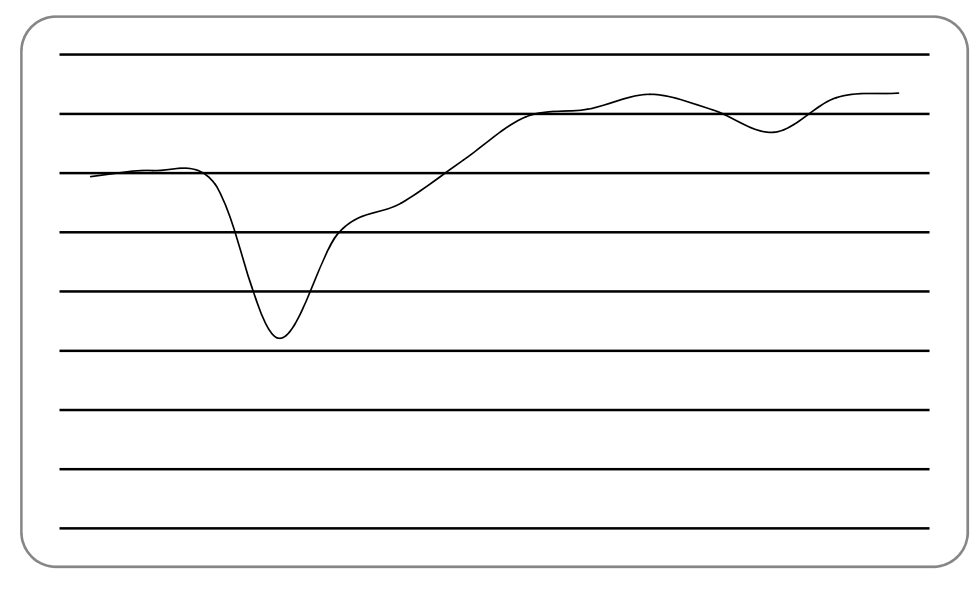

Source: Bureau of Economic Analysis

Figure 1. Corporate Profit (Billions) after Taxes between 2008 and 2011

\section{Economic Performance Analysis: GDP Growth Conditions}

Historical data on GDP growth show substantial variability between the first quarter of 2008 and second quarter of 2011. These fluctuations reflects periods of depressed performance after the 2008 recession. Trend analysis over this period show that GDP growth plummeted between the third quarter of 2008 and the second quarter of 2009 in responds to recessionary pressures over the period. For instance, according to the BEA annual percentage change in GDP growth was negative between the first and the second quarter of 2009 ( -6.7 and -0.7 respectively) due to lingering effects of the 2008 economic shock. This negative growth trend however, stabilized in the second quarter of 2009. Between the third quarter of 2009 up to the third quarter of 2011, the economy withnessed appreciable growth in GDP with much of the trend being driven by growth in consumpetion expenditure according to the BEA. The data further show that between the first quarter of 2009 and third quarter of 2011, about 70 percent of of GDP growth was due to growth in personal consumption expenditures; with investment growth accounting for just about 12 percent of the growth. This recorded appreciable growth in GDP notwithstanding, Bureau Labor Statistics data shows unemployment rate during the same period was persistently high. A condition which lend credence to the fact that, modest growth experienced over the period failed to singificantly reduce prevailing unemployment rate. Figure 2 reports GDP growth trends between first quarter of 2008 and first quarter of 2011. 


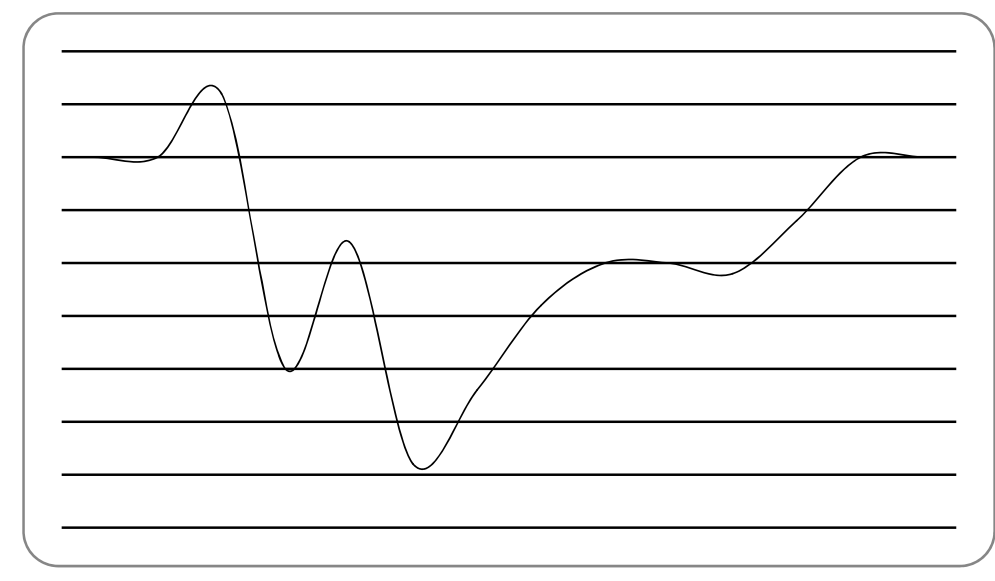

Source: Bureau of Economic Analysis

Figure 2. Gross Domestic Product Growth between 2008 and 2011

\section{Civilian Unemployment Rate Conditions}

According to the Bureau of Labor Statistics historical data, there have been five major surges in unemployment rate between 1960 and 2011. These surges have been characterized by unemployment rates of 7 percent and above. The first of these occurred in 1961 when unemployment rate of 7.1 percent was recorded in the month of May. The second surge following this period persisted over a two year period between 1975 and 1977; with the highest unemployment rate during the period reaching 9 percent in May of 1975. The most severe unemployment condition recorded within the period (1960 -2011) however, occurred between November and December of 1982. Relatively high unemployment conditions which started in the third quarter of 1980 continued to rise until it peaked at 10.8 percent in November and December of 1982 respectively. Unemployment rate after this period declined steadily until a measure of normalcy was recorded in the fourth quarter of 1986. The year 1992 also witnessed another surge in unemployment rate with the highest rate of 7.8 percent occurring in the month of June. Unemployment rates after this period (1992) barely rose beyond 6 percent until the fourth quarter of 2008 during the recent recession. Unemployment rate after the 2008 recession has since hovered over 8 percent to date (the first quarter of 2012). Although current unemployment rate pales in comparison to rates recorded in the first part of the $1980 \mathrm{~s}$, the current rate continues to have its own negative impact on the US economy. Ripple effects from the high unemployment rate continue to have significant negative impact on other key macroeconomic indicators in the economy. For instance, analysts suggest that high unemployment conditions leading to declining purchasing power might be responsible for depressed consumption expenditure and GDP growth. Figure 3 charts civilian unemployment conditions between the first quarter of 2008 and 2011.

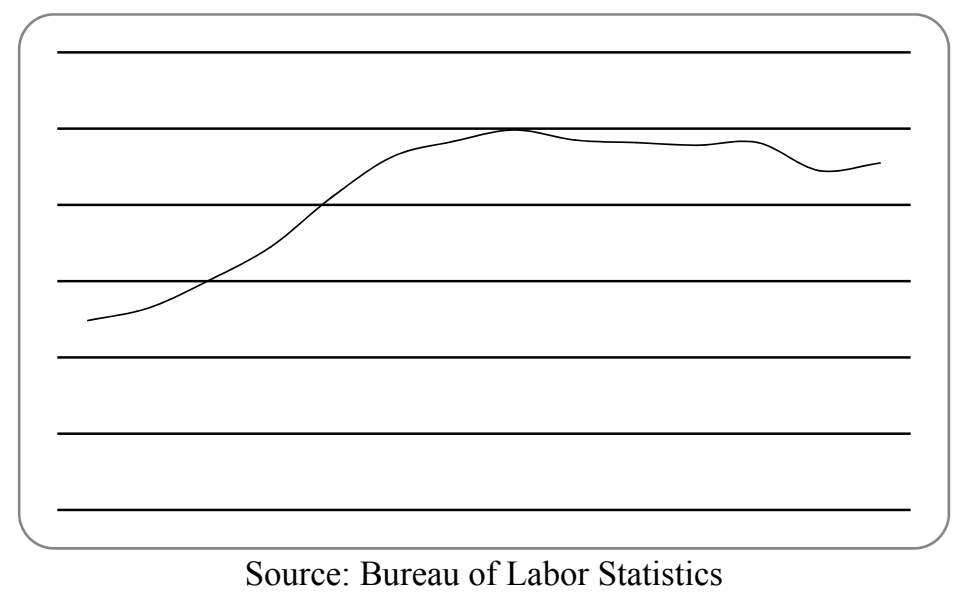

Figure 3. Civilian Unemployment conditions (Q1 2008 and Q1 2011) 


\section{Empirical Analyses}

This section outlines econometric model and other pre-test estimations employed in ascertaining the effect of corporate profit growth, trend GDP growth and other critical economic variables on US unemployment rate. The type and sources of data used in tests are first stated. This is followed by assessment of stationary conditions associated with time series variables tested in this study using Augmented Dicky-fuller unit root test procedure. The section further verifies cointegration conditions to assess long run associations if any, between core independent variables featured and unemployment rate. Long run test is conducted using Johansen Cointegration test procedure. Finally, I estimate effect of corporate profit growth, GDP growth, and other economic variables on the likelihood of having lower unemployment rate using marginal effects procedure in Probit statistical framework.

\subsection{Data Description and Variables}

This study features quarterly data spanning the period 1960 and 2011. Time series data over these periods are sourced from the Bureau of Economic Analysis, Bureau of Labor Statistics and St. Louis Fed database (FRED). Variables analyzed in this study include, unemployment rate (unemp), the dependent variable which is treated and coded as a binary variable to estimate the likelihood of lower unemployment rate $\mathrm{y}_{\mathrm{i}}=1$ or otherwise $\mathrm{y}_{\mathrm{i}}=0$. Explanatory variables tested in the study include corporate profits growth (corpp), non-financial sector corporate profits (nonf cp), productivity growth (prodty), labor cost (lcost), corporate fixed investment consumption (corpfic), GDP growth $(g d p g)$, macroeconomic uncertainty $(m u c)$ measured as the standard deviation of US GDP growth rate over specified data period; fixed investment growth (fig), consumption expenditure growth (ceg) and interest rate (ir). Analysis of the interaction between these performance and economic indicators and the likelihood of lower unemployment rate variable, forms the basis of conclusions made in this study.

\subsection{Econometric Analysis}

Test for stationary conditions of variables employed in the study using unit root testing methodology proposed by Dickey D A, Fuller W A (1981) is first conducted. Table 1 reports unit root test result. Initial unit roots test using specific lag and first difference results are reported. Results show that, given specified lag period (1), hypothesis of unit root cannot be rejected for most of the variables tested. Nonstationary variables in this case, satisfy the first condition in subsequent long run relationship test using Johanson cointegration procedure. Cointegration procedure in this context tests the condition that, although individual independent variables exhibits nonstationary trends, such trends might not be a 'random walk' with regards to how they relates to the study's dependent variable (unemployment rate) in the long run. In other words, unemployment rate trend might not be stationary, but its historical trend might for instance, have significant long run relationship with prevailing macroeconomic uncertainty or GDP growth etc. Table 1 report unit root results of individual variables and their first difference.

\subsubsection{Unit Root Test}

Table 1. Augmented Dicky-Fuller Test for Unit Roots

\begin{tabular}{lccclrr}
\hline Variables & ADF-Stats & Lags & Results & First Difference & ADF-Stats & Results \\
\hline UNEMP & -3.179 & 1 & I(1) & $\Delta$ UNEMP & -6.355 & $1(0)$ \\
CORPP & -0.959 & 1 & I(1) & $\Delta$ CORPP & -10.42 & $1(0)$ \\
NONFCP & -1.785 & 1 & I(1) & $\Delta$ NONFCP & -9.435 & $1(0)$ \\
PRODTY & -1.825 & 1 & I(1) & $\Delta$ PRODTY & -6.304 & $1(0)$ \\
LCOST & -1.323 & 1 & I(1) & $\Delta$ LCOST & -7.187 & $1(0)$ \\
CORFIC & -1.101 & 1 & I(1) & $\Delta$ CORFIC & -6.171 & $1(0)$ \\
GDPG & -2.987 & 1 & I(1) & $\Delta$ GDPG & -13.61 & $1(0)$ \\
FIG & -5.149 & 1 & I(0) & FIG & -5.149 & $1(0)$ \\
CEG & -6.713 & 1 & I(0) & CEG & -6.713 & $1(0)$ \\
MUC & -16.98 & 1 & I(0) & MUC & -16.98 & $1(0)$ \\
IR & -2.33 & 1 & I(1) & $\Delta$ IR & -10.74 & $1(0)$ \\
\hline
\end{tabular}

\subsubsection{Cointegration Estimation}

According to table 1, unemployment rate, the binary dependent variable is integrated in the order 1(1). Using this 
outcome, I test for cointegrating relationships between unemployment rate and individual independent variables integrated in the same order, i.e. I(1). Cointegration relationships between unemployment rate and independent variables with similar integration order are investigated by means of Johansen Maximum Likelihood cointegration technique. Table 2 reports evidence of long-run equilibrium relationship or otherwise, between unemployment rate and independent variables integrated in similar order. Out of eight long run relationship conditions tested, results show existence of long run relationship between unemployment rate and all explanatory variables tested with the exception of corporate profits growth (both corporate profit growth in general and nonfinancial corporate profit growth) and labor cost.

Table 2. Tests for Co integration

\begin{tabular}{lcccc}
\hline \multicolumn{1}{c}{ Variables } & $\mathbf{H}_{\mathbf{0}}$ & $\mathbf{H}_{\mathbf{1}}$ & Trace Statistics & Critical Value \\
\hline UNEMP (corpp) & $\mathrm{r}=0$ & $\mathrm{r} \geq 1$ & 13.14 & 15.41 \\
UNEMP (nonfcp) & $\mathrm{r}=0$ & $\mathrm{r} \geq 1$ & 12.07 &.. \\
UNEMP (prodty) & $\mathrm{r}=0$ & $\mathrm{r} \geq 1$ & $17.12^{*}$ &.. \\
UNEMP (lcost) & $\mathrm{r}=0$ & $\mathrm{r} \geq 1$ & 9.87 &.. \\
UNEMP (corfic) & $\mathrm{r}=0$ & $\mathrm{r} \geq 1$ & $16.61^{*}$ &.. \\
UNEMP (gdpg) & $\mathrm{r}=0$ & $\mathrm{r} \geq 1$ & $21.91^{*}$ &.. \\
UNEMP (ir) & $\mathrm{r}=0$ & $\mathrm{r}>1$ & $17.07^{*}$ &.. \\
\hline
\end{tabular}

*Condition of long term relationship between the variables

\subsection{Probit Framework}

\subsubsection{The Probit Model}

To estimate the probability of lower unemployment rate in the US using performance trend conditions associated with selected macroeconomic and performance indicators, the following probit function is first formulated:

$$
\operatorname{prob}\left[y_{i}=1\right]=f\left(\frac{b_{1}+b_{2} x_{i}}{\sigma}\right)
$$

where the probability of having lower unemployment rate $p\left[y_{\mathrm{i}}=1\right]$ is presumed to be a function of growth dynamics or fluctuations charactering selected independent variables in this study; $f$ denotes standard normal cumulative density function and $x_{\mathrm{i}}$ captures individual explanatory variables in the test. Equation 1 could further be restated as:

$$
\operatorname{prob}\left[y_{i}=1\right]=f\left(\frac{b_{1}+b_{2} x_{i}}{\sigma}\right)=\int_{-\infty}^{\frac{b_{1}+b_{2} x_{i}}{\sigma}} \frac{1}{\sqrt{2 \pi}} e^{-\frac{t^{2}}{2}} d t
$$

Equations 1 and 2 formulate the basic probit framework from which the potential for lower unemployment rate, given specific performance conditions among explanatory variables are derived. To verify the impact of individual variables on the probability of having lower unemployment rate, marginal effects of individual explanatory variables are derived using equation 1 . Using the chain rule, marginal effect of each explanatory variable on the potential for lower unemployment rate is modeled as follows:

$$
\frac{\partial \operatorname{prob}\left[y_{i}=1\right]}{\partial x_{i}}=\frac{\partial f\left(\frac{b_{1}+b_{2} x_{i}}{\sigma}\right)}{\partial x_{i}}=f\left(\frac{b_{1}+b_{2} x_{i}}{\sigma}\right) b_{2}
$$

Where, $x_{\mathrm{i}}$ captures specific independent variable whose marginal effect on the likelihood of lower unemployment rate is being tested or analyzed. Equation 3 (Note 3), a nonlinear function, in this case is evaluated at the mean of individual explanatory variables. Equation 3 measures the potential for lower unemployment rate associated with individual explanatory variables; it estimates the probability of lower unemployment rate; that is $\left[y_{i}=1\right]$ given a percentage growth (change) in an independent variable. Table 3 reports ordinary least square (OLS), Probit and Marginal effects Probit estimates of the likelihood of a lower unemployment rate in the US. 
6.3.2 Effects of Growth Performance on the Likelihood of Lower Unemployment Rate

Table 3. Variables OLSProbit Marginal Effects

\begin{tabular}{|c|c|c|c|}
\hline Variables & $\begin{array}{l}\text { Coefficients } \\
\text { (Std Errors) }\end{array}$ & $\begin{array}{l}\text { Coefficients } \\
\text { (Std Errors) }\end{array}$ & $\begin{array}{l}\text { Coefficients } \\
\text { (Std Errors) }\end{array}$ \\
\hline Corporate Profits & $\begin{array}{l}0.0014^{*} \\
(0.0007)\end{array}$ & $\begin{array}{l}0.0111^{*} \\
(0.0052)\end{array}$ & $\begin{array}{l}0.0037^{*} \\
(0.0017)\end{array}$ \\
\hline Nonfinancial Corp Profits & $\begin{array}{l}-0.0028^{* *} \\
(0.0010)\end{array}$ & $\begin{array}{l}-0.0196^{* *} \\
(0.0068)\end{array}$ & $\begin{array}{l}-0.0066^{* *} \\
(0.0023)\end{array}$ \\
\hline Productivity Growth & $\begin{array}{c}-0.1003^{* * *} \\
(0.0097)\end{array}$ & $\begin{array}{l}-0.5323^{* * *} \\
(0.0786)\end{array}$ & $\begin{array}{l}-0.1770^{* * *} \\
(0.0239)\end{array}$ \\
\hline Corp fix Con Investments & $\begin{array}{l}0.0042^{* * *} \\
(0.0009)\end{array}$ & $\begin{array}{l}0.0213^{* * *} \\
(0.0057)\end{array}$ & $\begin{array}{l}0.0071^{* * *} \\
(0.0019)\end{array}$ \\
\hline GDP Growth & $\begin{array}{c}0.0524^{*} \\
(0.0278)\end{array}$ & $\begin{array}{c}0.4940^{* *} \\
(0.1660)\end{array}$ & $\begin{array}{l}0.1463^{* *} \\
(0.0522)\end{array}$ \\
\hline Fixed Investment Growth & $\begin{array}{l}0.0110^{* *} \\
(0.0037)\end{array}$ & $\begin{array}{l}0.0609^{* *} \\
(0.0215)\end{array}$ & $\begin{array}{l}0.0202^{* *} \\
(0.0071)\end{array}$ \\
\hline Consumption Exp Growth & $\begin{array}{l}-0.0073 \\
(0.0125)\end{array}$ & $\begin{array}{c}-0.0118 \\
(0.0598)\end{array}$ & $\begin{array}{l}-0.0039 \\
(0.0199)\end{array}$ \\
\hline Interest Rate & $\begin{array}{c}-0.0636^{* * *} \\
(0.0151)\end{array}$ & $\begin{array}{l}-0.3860^{* * *} \\
(0.0925)\end{array}$ & $\begin{array}{l}-0.1284^{* * *} \\
(0.0306)\end{array}$ \\
\hline GD Private Inv Growth & $\begin{array}{l}0.0496^{* *} \\
(0.0164)\end{array}$ & $\begin{array}{c}0.1371 \\
(0.0868)\end{array}$ & $\begin{array}{c}0.0456 \\
(0.0296)\end{array}$ \\
\hline Macroeconomic Uncertainty & $\begin{array}{l}-0.0720 \\
(0.0551)\end{array}$ & $\begin{array}{l}-0.6994^{*} \\
(0.3138)\end{array}$ & $\begin{array}{l}-0.2326^{*} \\
(0.1015)\end{array}$ \\
\hline _cons & $\begin{array}{l}(1.7789) \\
(0.1957)\end{array}$ & $\begin{array}{c}6.6031 \\
(1.2233)\end{array}$ & $(0.000)$ \\
\hline$N$ & $\begin{array}{c}205 \\
\mathrm{r}^{2}=0.50\end{array}$ & $\begin{array}{c}205 \\
\text { Pseudo } r^{2}=0.52\end{array}$ & $\begin{array}{c}205 \\
\text { Pseudo } r^{2}=0.51\end{array}$ \\
\hline
\end{tabular}

Standard errors in parentheses

${ }^{*} p<0.05,{ }^{* *} p<0.01,{ }^{* * *} p<0.001$

*Above results controls for possible effects of labor cost on probability of lower unemployment conditions

\section{Potential for Lower US Unemployment Rate Analysis}

Coefficient estimates of the likelihood of lower unemployment rate given a percentage change/growth in an explanatory variable are discussed in this section. Results presented in table 3 show that corporate profit growth is significant in determining swings or trends in unemployment rate as some analysts espouse. Estimated coefficient however, indicates that corporate profits growth exerts relatively weak influence on unemployment rate compared to other independent variables tested in this study. Coefficient associated with the variable show that all else held constant, percentage growth in corporate profits in general enhances the likelihood of lower unemployment rate by 0.4 percent; a relatively significant impact which to some degree might explain growing debate on the mismatch between recent corporate profit growth trend and unemployment conditions; in that recent trends in corporate profit growth and unemployment conditions challenges this empirical estimates. In other words, verified estimates indicates 5 percent growth in corporate profits is projected to boosts the potential for lower unemployment rate by 2 
percent all things being equal. This outcome, (which conflicts recent trends on the relationship between the two variables) might help explain why some analysts are baffled by positive correlation between recent unemployment rate and corporate profit growth; in that, if above estimated coefficient driven by available data accurately captures the relationship between the two variables, then recent growth in corporate profits should have had significant impact on efforts aimed at lowering prevailing unemployment rate all things being equal.

This outcome to some extent support the notion that recent corporate profits growth might reflects accrued profits from abroad by international subsidiaries of US firms with little or no link to domestic investments or operations as some analysts have argued. Table 3 additionally reports that nonfinancial sector profit growth is also significant in augmenting the potential for lower unemployment rate. However, the outcome is negative, suggesting an opposite effect on the probability of having lower unemployment rate. Percentage growth in non-financial corporate profit fails to have projected impact on unemployment rate; the condition rather decreases the likelihood of having lower unemployment rate by 0.7 percent all things being equal- a condition which best fit current relationship between corporate profit growth and unemployment rate. To ascertain potential factors which might explain this outcome, individual variables were revaluated and relevant literature reviewed for clues; however, I find no plausible explanation for the condition apart from the possibility that increasing profit margins might have accrued from lower labor cost due to high rate of layoffs which characterized post recession firm operations. Additionally, the condition might also stem from moderating and interaction effects from other variables employed which this study tried to control for.

Apart from corporate profits growth dynamics, marginal effect coefficients further show that domestic productivity level, GDP growth, interest rates fluctuations, private fixed investment growth, corporate fixed expenditure growth and macroeconomic uncertainty are all significant in assessing the likelihood of having lower unemployment rate. This study finds that productivity growth and unemployment rate might not necessarily follow known traditional paradigm suggesting a negative association between the two variables. I find that all things being equal, percentage growth in productivity may not necessarily augment the likelihood of having lower unemployment rate. Result show that sustained productivity growth might rather depress the potential of lower unemployment rate. Percentage growth in productivity is found to reduce the likelihood of lower unemployment rate by as much as 17 percent. Although this outcome defies espoused views on the relationship between the two variables, it is cogent to note that significant portion of growth in productivity in recent years tend to be less labor intensive (mainly driven by advances in technology). This result therefore suggests that recent growth in productivity might have resulted from efficient utilization of advanced technologies with little relation to the size of the labor force employed. If sustained productivity growth is predominantly driven by excessive deployment of advanced technologies, then, the condition will rather lead to relatively high unemployment conditions rather than reduce it. This outcome to some extent projects that productivity might expand as more advanced production technologies are adopted, without significant growth in employment as expected.

Growth in fixed investment consumption among firms is also found to be highly significant in determining the likelihood of lower unemployment rate. However, its impact is relatively modest compared to other variables tested in the study. Marginal effect coefficient shows that percentage growth in corporate fixed investments consumption increases the likelihood of lower unemployment condition by 0.7 percent. This outcome (as defined by coefficient estimate) suggests that corporate investments growth alone might not be enough to overcome high unemployment conditions in the US economy. Overall GDP growth is also significant in assessing the likelihood of lower unemployment rate as expected. Percentage growth in GDP increases the likelihood of lower unemployment condition by approximately 15 percent. This result is highly significant in that, it supports growing view suggesting that, for efforts aimed at reducing high unemployment rate to be successful, it should focus on addressing how to facilitate significant growth in GDP. It further lends credence to the fact that sustained growth in GDP is still a key performance indicator with the potential to significantly accelerate job growth.

Fixed investment growth in general is also found to have significant impact on US unemployment rate. Percentage growth in fixed investment increases the likelihood of lower unemployment rate by 2 percent. However, I find that growth in consumption expenditure, a substantial segment of GDP growth (70 percent of GDP growth according to BEA) is insignificant in assessing the likelihood of lower unemployment rate. This outcome is puzzling in that, it is at variance with pre-test correlation analysis indicating that the variables are negatively correlated (-0.0643) (Note 4). Given that consumption expenditure constitutes about 70 percent of US GDP growth according to BEA estimates (which has already been found to be significant), this study anticipated that growth in consumption expenditure will also have significant impact on the likelihood of having lower unemployment conditions. The result however indicates otherwise. This result however, could to some extent explain recent mismatch between consumption expenditure and unemployment rate. According to BEA, although consumption expenditure continues to experience 
appreciable growth since 2010 , the improvement has so far failed to significantly influence persistently high unemployment rate.

To further examine factors responsible for this outcome (why consumption expenditure growth is insignificant in determining the likelihood of having lower unemployment rate) historical data trends for the two variables (between the period 1960 and 2011) were analyzed. Historical trend analysis indicates that the relationship between the two variables has not always been negative through time as traditionally projected. There are trend instances (e.g. early 1970s, 1982-86 and in the 1990s) where the two variables have trended in the same direction contrary to traditionally espoused relationship between the variables. Again, the data also show that there have been instances where variability in consumption expenditure growth has had little or no significant impact on prevailing unemployment rate over the same period. For instance, this study's review of the data shows that fluctuations in consumption expenditure growth between the mid 1960s and early part of 1990s do not fully explain unemployment trends over the same period. Additionally, recent data further show that although consumption expenditure since the 2008 recession continues to show significant recovery, unemployment conditions over the same period have been persistently high. This inconsistent relationship between the two variables might explain above test outcome suggesting that consumption expenditure growth is insignificant in determining the likelihood of having lower unemployment rate or predicting unemployment rate trend.

Interest rate fluctuations are found to be significant in determining the likelihood of having lower unemployment rate. Marginal effect estimate indicates that percentage increase in prevailing interest rate decreases the probability of having lower unemployment condition by approximately 13 percent. This result is also significant because it supports ongoing Federal Reserve policy of maintaining low interest rate in an attempt to augment efforts at improving conditions for growth and reducing unemployment rate. Although fixed investment growth in general is found to be significant in assessing the likelihood of lower unemployment rate, this study find that gross domestic private investment growth is insignificant; suggesting that private investment growth alone might not be enough in accelerating employment growth in the US economy.

Finally, marginal effect estimates shows that macroeconomic uncertainty (as measured by volatility associated with GDP growth), has significant impact on the likelihood of lower unemployment rate. Coefficient estimate show that heightened macroeconomic uncertainty all things being equal, negatively impact the likelihood of lower unemployment conditions in the US economy. Percentage growth in the degree of macroeconomic uncertainty, (for instance, about the trajectory of the economy due to depress GDP growth) decreases the likelihood of lower unemployment rate by as much as 23 percent. In other words, among variables perceived as having significant impact on prevailing US unemployment rates, macroeconomic uncertainty might be the dominant condition. This result further suggests that, uncertain macroeconomic conditions tend to drive more of the variability in unemployment rate than other known determinants tested. Consequently, to bring about significant reduction in unemployment conditions, this result suggests the need for governing bodies to pursue policies geared towards restoring confidence in the economy. This could be done through specific, well-defined long term policy initiatives designed to reduce perceived uncertainty among potential investors as well as consumers. Long term policies with clear objectives geared towards improving the state of the economy for instance, could serve as a catalyst which can set in motion trends critical for sustain growth.

\section{Conclusion}

This study investigated the potential for lower unemployment conditions in the US given performance conditions associated with key macroeconomic and performance indicators. I find that both corporate profit growth and GDP growth are significant in enhancing the potential for lower unemployment rate. Among the variables tested however, reduction in macroeconomic uncertainty is found to be the dominant condition with the potential to significantly reduce relatively high unemployment rate in the US economy.

\section{References}

Aizenman, J., \& Marion, N. (1999). Volatility and Investment: Interpreting Evidence from Developing Countries. Economica, 66, 157-179. http://dx.doi.org/10.1111/1468-0335.00163

Arestis, P., Baddeley. M., \& M. Sawyer (2007). The relationship between capital stock, unemployment and wages in nine EMU countries. Bulletin of Economic Research, 59(2), 125-148. http://dx.doi.org/10.1111/j.0307-3378.2007.00254.x

Asteriou, Dimitrios, \& Simon Price. (2005). Uncertainty, Investment and Economic Growth: Evidence from a $\begin{array}{lllll}\text { Dynamic Panel. Review of Development } & \text { Economics } & \text { 9(2), } & \text { 277-288. }\end{array}$ http://dx.doi.org/10.1111/j.1467-9361.2005.00276.x 
Brady D., \& M. Wallace. (2000). Spatialization, Foreign Direct Investment, and Labor Outcomes in the American States, 1978-1996. Social Forces, 79(1), 67-105.

Bureau of Economics Analysis Release. (2011). Corporate Profits, 2nd quarter 2011 (revised estimate) Sept 29.

Bureau of Labor Statistics Quarterly Data on Unemployment Rates between 1960 and 2011.

Dickey D. A., \& Fuller W. A. (1981). Likelihood ratio statistics for autoregressive time series with a unit root. Econometrica, 49, 1057-1071. http://dx.doi.org/10.2307/1912517

Edwards, S. (1989). Real Exchange Rate in the Developing Countries: Concepts and Measurement, NBER Working Paper, 2950 (Cambridge, NBER).

Eita Hinaunye Joel, \& Ashipala Johannes. (2010). Determinants of Unemployment inNamibia. International Journal of Business and Management, 5(10).

Federer, J. (1993). The Impact of Uncertainty on Aggregate Investment Spending. Journal of Money, Credit and Banking, 25, 30-48. http://dx.doi.org/10.2307/2077818

Hertbertson, T., \& G. Zoega. (2002). The Modigliani Puzzle. Economics Letters, 76(3), 437-442. http://dx.doi.org/10.1016/S0165-1765(02)00089-7

Johansen, S. (1988). Statistical Analysis of Cointegrating Vectors. Journal of Economics Dynamics and Control, 12, 231-254. http://dx.doi.org/10.1016/0165-1889(88)90041-3

Kapadia, S. (2005). The Capital stock and equilibrium unemployment: a new theoretical perspective. Balliol College, University of Oxford. Department of Economics, Discussion Paper 181.

Karanassou M., Sala H., \& P. F. Salvador. (2008). Capital Accumulation and Unemployment: New Insights on the Nordic Experience. Cambridge Journal of Economics, 32, 977-1001. http://dx.doi.org/10.1093/cje/ben022

Moguillansky, G. (2002). Investment and Financial Volatility in Latin America. CEPAL Review, 77, 45-63.

Ramey, G., \& V. A. Ramey. (1995). Cross-Country Evidence on the Link between Volatility and Growth. American Economic Review, 85(5), 1138-51.

Sawyer. (2002). The NAIRU, Aggregate Demand and Investment. Metroeconomica, 53(1), 66-94.

Smith, R., \& G. Zoega. (2005). Unemployment, Investment and Global Expected Returns: A panel FAVAR approach. Birkbeck College, School of Economics, Mathematics and Statistics. Working Paper BWPEF 0524

Spence, Michael. (Jul/Aug 2011). Foreign Affairs 90, 4, 28-41. Retrieved from www.foreignaffairs.com/articles/.../globalization-and-unemployment

St Louis Fed Data Base (FRED). (2012). Data on Major Macroeconomic indicators. Downloaded on 01/25.

\section{Notes}

Note 1. (In an essay entitled: Globalization and Unemployment: the downside of integrating markets - July-August 2011)

Note 2. Linked with Spencer's argument.

Note 3. Partial derivative of equation 1

Note 4. Correlation matrix conducted is based on quarterly data series between 1960 and 2011. 